УДК 342.981

DOI 10.18413/2712-746X-2020-44-3-558-564

\title{
Гарантирование избирательного права: российский законодательный опыт
}

\author{
Троян В.A. \\ Белгородский государственный национальный исследовательский университет, \\ Россия, 308015, г. Белгород, ул. Победы, 85 \\ E-mail: troyan@bsu.edu.ru
}

\begin{abstract}
Аннотация. Представлены результаты сравнительно-правового исследования законодательных актов различного периода развития российского государства в связи с выявлением в них норм, гарантирующих избирательное право. Уставлено, что с 1978 г. по настоящее время длится фрагментарно-специальный законодательный этап формализации гарантий субъективного избирательного права, который автор связал с тем, что в нормативных правовых актах в форме законов, посвященных выборам различного уровня, в корреляции с избирательным правом использован термин «гарантии». С принятием в 1997 г. федерального закона № 124-Ф3 «Об основных гарантиях избирательных прав и права на участие в референдуме граждан Российской Федерации» начался рамочно-специальный законодательный этап формализации гарантий субъективного избирательного права в России, связанный с наличием особого документа универсально консолидировавшего искомые гарантии. Правовые нормы отмеченных периодов являются частью конституционно-правовой системы гарантирования субъективного
\end{abstract} избирательного права в России.

Ключевые слова: права человека, гарантии, субъективное избирательное право, гарантии избирательного права, закон, выборы, референдум.

Для цитирования: Троян В.А. 2020. Гарантирование избирательного права: российский законодательный опыт. NOMOTHETIKA: Философия. Социология. Право. 45 (3): 558-564. DOI 10.18413/2712-746X-2020-44-3-558-564

\section{Guaranteeing the right to vote: Russian legislative experience}

\author{
Vladimir A. Troyan \\ Belgorod National Research University, \\ 85 Pobeda St, Belgorod, 308015, Russia \\ E-mail: troyan@bsu.edu.ru
}

\begin{abstract}
The article presents the results of a comparative legal study of legislative acts of various periods of development of the Russian state in connection with the identification of norms in them that guarantee the right to vote. It is stated that from 1978 to the present time there has been a fragmentary special legislative stage of formalization of guarantees of subjective electoral rights, which the author linked to the fact that the term "guarantees» is used in normative legal acts in the form of laws on elections of various levels, in correlation with the electoral law. With the adoption in 1997 of Federal law № 124-FZ «On basic guarantees of electoral rights and the right to participate in a referendum of citizens of the Russian Federation», a framework-specific legislative stage of formalization of guarantees of subjective electoral rights in Russia began, associated with the presence of a special document that universally consolidated the sought guarantees. The legal norms of these periods are part of the constitutional and legal system for guaranteeing subjective suffrage in Russia.
\end{abstract}

Keywords: human rights, the guarantees of the subjective suffrage, guarantees of the electoral rights, the law, elections, referendum. 
For citation: Troyan V.A. 2020. The methodology of science and applied analytics: the parameter of completeness of coverage and completeness of accounting for the determining factors in the study. NOMOTHETIKA: Philosophy. Sociology. Law series. 45 (3): 558-564 (in Russian). DOI 10.18413/2712-746X-2020-44-3-558-564

\section{Введение}

Проблема юридических гарантий неизменно находится в фокусе научного внимания общетеоретического уровня [Лошкарев, 2009; Вискулова, 2013] и отдельных отраслей права [Агишев, 2014; Чихладзе, Осавелюк, 2018].

В рамках конституционно-правовой науки юридические гарантии, полагаем, обоснованно выступают элементами научных теорий правового статуса личности [Нудненко, Тхабисимова, 2016; Федотова, 2017], деятельности государственных органов в аспекте обеспечения субъективных прав [Новикова, 2007; Трещева, Балаян, 2019], их реализации [Kornyushkina et al., 2017; Чуклин, 2016]. Следуя данному подходу, в настоящей работе исследованы законы, гарантирующие избирательное право граждан в различные периоды развития российского государства.

\section{Фрагментарно-специальный законодательный этап формализации гарантий субъективного избирательного права}

Итак, с 1978 г. по настоящее время - фрагментарно-специальный законодательный этап формализации гарантий субъективного избирательного права. Его мы связываем с тем, что в нормативных правовых актах в форме законов, посвященных выборам различного уровня, в купе с избирательным правом начали использовать термин «гарантии».

Принятые, начиная с советского периода развития России, законы, были посвящены выборам Верховного Совета РСФСР ${ }^{1}$, местных советов народных депутатов РСФСР², районных (городских) народных судов РСФСР ${ }^{3}$, народных депутатов местных советов народных депутатов РСФСР 4 , Президента ${ }^{5}$, депутатов Государственной Думы Федерального Собрания Российской Федерации ${ }^{6}$ (перечисление соответствует хронологии появле-

1 Закон РСФСР от 08.08.1978 «О выборах в Верховный Совет РСФСР» // Ведомости ВС РСФСР. 1978. № 32. СТ. 845.

2 Закон РСФСР от 03.08.1979 г. «О выборах в местные Советы народных депутатов РСФСР» // Ведомости ВС РСФСР. 1979. № 32. Ст. 784.

3 Закон РСФСР от 08.07.1981 «О выборах районных (городских) народных судов РСФСР» // Ведомости ВС РСФСР. 1981. № 28. Ст. 977.

${ }^{4}$ Закон РСФСР от 27.10.1989 «О выборах народных депутатов местных Советов народных депутатов РСФСР» // Ведомости ВС РСФСР. 1989. № 44. Ст. 1306.

${ }^{5}$ См.: Закон РСФСР от 24.04.1991 г. № 1096-1 «О Выборах Президента РСФСР» // Ведомости СНД и ВС РСФСР. 1991. № 17. Ст. 510; федеральные законы от 17.05.1995 № 76-Ф3 «О выборах Президента Российской Федерации» // Российская газета. 1995, 23 мая; от 31.12.1999 № 228Ф3 «О выборах Президента Российской Федерации» // С3 РФ. 2000. № 1 (ч. II). Ст. 11; от 10.01.2003 № 19-Ф3 «О выборах Президента Российской Федерации» (ред. от 23.05.2020 г.) // С3 РФ. 2003. № 2. Ст. 171; 2020. № 21. Ст. 3232.

${ }^{6}$ См.: федеральные законы от 21.06.1995 г. № 90-Ф3 «О выборах депутатов Государственной Думы Федерального Собрания Российской Федерации» // Российская газета. 1995, 28 июня; от 24.06.1999 № 121-Ф3 «О выборах депутатов Государственной Думы Федерального Собрания Российской Федерации» // С3 РФ. 1999. № 26. Ст. 3178; от 20.12.2002 № 175-Ф3 «О выборах депутатов Государственной Думы Федерального Собрания Российской Федерации» // С3 РФ. 2002. № 51. Ст. 4982; от 18.05.2005 № 51-Ф3 «О выборах депутатов Государственной Думы Федерального Собрания Российской Федерации» // СЗ РФ. 2005. № 21. Ст. 1919; от 22.02.2014 № 20-Ф3 «О выборах 
ния правовых актов). Гарантии в приведенных документах формулировались в идентичном смысловом значении, как правило, в самостоятельных главах или статьях и касались:

- свободного и всестороннего обсуждения гражданами РСФСР и общественными организациями политических, деловых и личных качеств кандидатов в депутаты, а также права агитации на собраниях, в печати, по телевидению, радио (ст. 10 Закона РСФСР от 8 августа 1978 г., ст. 10 Закона РСФСР от 3 августа 1979 г., ст. 12 Закона РСФСР от 8 июля 1981 г., ст. 42 Закона РСФСР от 27 октября 1989 г.);

- права каждого гражданина участвовать в предвыборной агитации (ст. 43 Закона РСФСР от 8 августа 1978 г., ст. 42 Закона РСФСР от 3 августа 1979 г., ст. 42 Закона РСФСР от 8 июля 1981 г., ст. 42 Закона РСФСР от 27 октября 1989 г., ст. 4 Закона РСФСР от 24 апреля 1991 г. № 1096-1);

- права на предвыборную агитацию с равными условиями доступа к государственным средствам массовой информации (ст. 8 Федерального закона от 21 июня 1995 № 90Ф3, ст. 7 Федерального закона от 17 мая 1995 № 76-Ф3, ст. 8 Федерального закона от 31 декабря 1999 г. № 228-Ф3, ст. 8 Федерального закона от 20 декабря 2002 г. № 175-Ф3, ст. 8 Федерального закона от 10 января 2003 г. № 19-Ф3, ст. 10 Федерального закона от 18 мая 2005 г. № 51-Ф3, ст. 9 Федерального закона от 22 февраля 2014 г. № 20-Ф3);

- деятельности кандидата, включая его

неприкосновенность (ст. 47 Закона РСФСР от 8 августа 1978 г., ст. 9 Закона РСФСР от 24 апреля 1991 г. № 1096-1, ч. 7 ст. 49 Федерального закона от 24 июня 1999 г. № 121Ф3, ч. 6 ст. 41 Федерального закона от 31 декабря 1999 г. № 228-Ф3, ч. 7 ст. 50 Федерального закона от 20 декабря 2002 г. № 175-Ф3, ч. 6 ст. 42 Федерального закона от 10 января 2003 г. № 19-Ф3, ч. 3 ст. 47 Федерального закона от 18 мая 2005 г. № 51-Ф3, ч. 3 ст. 54 Федерального закона от 22 февраля 2014 г. № 20-Ф3);

право выступать на собраниях и митингах, пользоваться средствами массовой информации (ст. 44 Закона РСФСР от 8 августа 1978 г., ст. 43 Закона РСФСР от 3 августа 1979 г., ст. 43 Закона РСФСР от 8 июля 1981 г.);

право участвовать в предвыборной кампании, выступая на собраниях, совещаниях, заседаниях, в печати, по телевидению, радио (ст. 39) с предвыборной программой (ст. 40) с привлечением помощи доверенных лиц (ст.ст. 41 Закона РСФСР от 27 октября 1989 г., ст. 9 Закона РСФСР от 24 апреля 1991 г. № 1096-1);

освобождение от производственных или служебных обязанностей для участия в предвыборных мероприятиях (ст.ст. 45 Закона РСФСР от 8 августа 1978 г., ст. 44 Закона РСФСР от 3 августа 1979 г., ст. 44 Закона РСФСР от 8 июля 1981 г., ст. 9 Закона РСФСР от 24 апреля 1991 г. № 1096-1, ч. 1 ст. 49 Федерального закона от 24 июня 1999 г. № 121Ф3, ч. 1 ст. 41 Федерального закона от 31 декабря 1999 г. № 228-Ф3, ч. 1 ст. 50 Федерального закона от 20 декабря 2002 г. № 175-Ф3, ч. 1 ст. Федерального закона от 10 января 2003 г. № 19-Ф3, ч. 1 ст. 47 Федерального закона от 18 мая 2005 г. № 51-Ф3 ч. 1 ст. 54 Федерального закона от 22 февраля 2014 г. № 20-Ф3);

право на бесплатный проезд (ст. 46 Закона РСФСР от 8 августа 1978 г., ст. 9 Закона РСФСР от 24 апреля 1991 г. № 1096-1, чч. 2-5 ст. 49 Федерального закона от 24 июня 1999 г. № 121-Ф3, чч. 2-4 ст. 41 Федерального закона от 31 декабря 1999 г. № 228-Ф3, чч. 2-5 ст. 50 Федерального закона от 20 декабря 2002 г. № 175-Ф3);

обеспечение равными с другими зарегистрированными кандидатами возможностями материально-технического и финансового обеспечения избирательной кампании (ст. 9 Закона РСФСР от 24 апреля 1991 г. № 1096-1);

депутатов Государственной Думы Федерального Собрания Российской Федерации» (ред. от 23.05.2020) // СЗ РФ. 2014. № 8. Ст. 740; 2020. № 21. Ст. 3233. 
невозможность увольнения с работы, а также переведения на другую работу или должность без согласия (ст. 9 Закона РСФСР от 24 апреля 1991 г. № 1096-1, ч. 6 ст. 49 Федерального закона от 24 июня 1999 г. № 121-Ф3, ч. 5 ст. 41 Федерального закона от 31 декабря 1999 г № 228-Ф3, ч. 6 ст. 50 Федерального закона от 20 декабря 2002 г. № 175-Ф3, ч. 5 ст. 42 Федерального закона от 10 января 2003 г. № 19-Ф3, ч. 2 ст. 47 Федерального закона от 18 мая 2005 г. № 51-Ф3, ч. 2 ст. 54 Федерального закона от 22 февраля 2014 г. № 20-Ф3);

право на получение в соответствующей избирательной комиссии субъекта Российской Федерации списка избирательных участков с указанием их границ, адресов и телефонов территориальных и участковых избирательных комиссий, адресов помещений для голосования (ч. 8 ст. 49 Федерального закона от 24 июня 1999 г. № 121-Ф3, ч. 7 ст. 41 Федерального закона от 31 декабря 1999 г. № 228-Ф3, ч. 8 ч. 1 ст. 50 Федерального закона от 20 декабря 2002 г. № 175-Ф3, ч. 7 ст. 42 Федерального закона от 10 января 2003 г. № 19-Ф3);

утрату прав и освобождение от обязанностей, связанных со статусом зарегистрированного кандидата, со дня официального опубликования общих результатов выборов (ч. 8 ст. 41 Федерального закона от 31 декабря 1999 г. № 228-Ф3, ч. 8 ст. 42 Федерального закона от 10 января 2003 г. № 19-Ф3);

снятие кандидатуры в любое время до выборов (ст. 9 Закона РСФСР от 24 апреля 1991 г. № 1096-1).

Дополнительно к перечисленным в ст. 37 Федерального закона от 18 мая 2005 г. № 51-Ф3 были предусмотрены гарантии реализации пассивного избирательного права граждан, не являющихся членами политических партий.

Интересно, что ранее действовавший федеральный конституционный закон от 10 октября 1995 г. «О референдуме Российской Федерации» вообще не содержал термин «гарантии» ${ }^{1}$ в отличие от аналогичного действующего акта ${ }^{2}$. В его преамбуле дважды употребляется термин «гарантии»: в связи с государственным гарантированием свободного волеизъявления граждан Российской Федерации на референдуме Российской Федерации, защиты демократических принципов и норм права, определяющих право граждан на участие в референдуме.

В ч. 3 ст. 11 указанного федерального конституционного закона формализованы государственные гарантии проведения агитации по вопросам референдума.

$\mathrm{C}$ наступлением законодательного этапа гарантирования субъективного избирательного права, тем не менее, сохраняют свою гарантирующую роль и подзаконные нормативные правовые акты, конкретизирующие законодательные ${ }^{3}$.

${ }^{1}$ Федеральный конституционный закон от 10 октября 1995 г. № 2-ФКЗ «О референдуме Российской Федерации» (ред. от 28.06.2004 г.) // СЗ РФ. 1995. № 42. Ст. 3921.

${ }^{2}$ Федеральный конституционный закон от 28 июня 2004 г. № 5-ФКЗ «О референдуме Российской Федерации» (ред. от 18.06.2017 г.) // С3 РФ. 2004. № 27. Ст. 2710; 2017. № 25. Ст. 3589.

${ }^{3}$ См.: Постановления ЦИК России от 12.01.2018 № 126/1059-7 «О Методических рекомендациях по обеспечению реализации избирательных прав военнослужащих и сотрудников правоохранительных органов при проведении выборов Президента Российской Федерации» // Вестник ЦИК России. 2018. № 2; от 20.06.2018 № 164/1338-7 «О Рекомендациях по обеспечению избирательных прав граждан Российской Федерации, являющихся инвалидами, при проведении выборов в Российской Федерации» (ред. от 19.06.2019) // Вестник ЦИК России. 2018. № 12; 2019. № 5; от 24.05.2017 № 83/720-7 «Об обеспечении избирательных прав кандидатов, выдвинутых по одномандатным избирательным округам политическими партиями, а также в порядке самовыдвижения, при приеме окружными избирательными комиссиями документов для выдвижения, регистрации, а также иных избирательных документов при проведении дополнительных выборов депутатов Государственной Думы Федерального Собрания Российской Федерации седьмого созыва по одномандатным избирательным округам» // Вестник ЦИК России. 2017. № 5 и др. 


\section{Рамочно-специальный законодательный этап формализации гарантий субъективного избирательного права}

С принятием в 1997 г. федерального закона № 124-Ф3 «Об основных гарантиях избирательных прав и права на участие в референдуме граждан Российской Федерации», полагаем, начался рамочно-специальный законодательный этап формализации гарантий субъективного избирательного права в России ${ }^{1}$. Преамбула указанного акта зафиксировала, что государством гарантируются свободное волеизъявление граждан на выборах и референдуме, защита демократических принципов и норм избирательного права и права на участие в референдуме.

В данном федеральном законе легализована дефиниция гарантий избирательных прав и права на участие в референдуме в качестве правового, организационного, информационного и иного обеспечения избирательных прав и права на участие в референдуме граждан Российской Федерации (ст. 2); определены пределы действия федерального закона (ст. 1); установлены гарантии избирательных прав граждан на проведение выборов при отсутствии закона субъекта Российской Федерации о выборах (ст. 11), гарантии деятельности зарегистрированных кандидатов (ст. 35), гарантии избирательных прав граждан на проведение выборов при отсутствии закона субъекта Российской Федерации о выборах (ст. 44).

Несмотря на то, что федеральный закон от 19 сентября 1997 г. № 124-Ф3, исходя из наименования, явился первым специальным законодательным актом, консолидировавшим гарантии субъективного избирательного права, лишь некоторые его статьи непосредственно используют термин «гарантии». Хотя не отрицаем, что в целом закон им и посвящен. Однако считаем композиционно и содержательно более удачным Федеральный закон от 12 июня 2002 г. № 67-Ф3 «Об основных гарантиях избирательных прав и права на участие в референдуме граждан Российской Федерации» ${ }^{2}$. Практически каждая из его глав, посвященных отдельным стадиям или аспектам избирательного процесса, изложена с акцентом гарантирования. Отметим, что такой законодательный подход соответствует и ранее избранному нами доктринальному подходу, применительно к конституционным нормам, а также нормам подзаконных актов советского периода [Троян, 2020].

В пользу перехода к новому этапу законодательного гарантирования избирательного права также свидетельствует тот факт, что в специально-фрагментарных федеральных законах давалась бланкетная норма на федеральный закон «Об основных гарантиях избирательных прав и права на участие в референдуме граждан Российской Федерации»: в федеральных законах от 24 июня 1999 г. № 121-Ф3 12 раз, от 31 декабря 1999 г. № 228-Ф3 10, от 20 декабря 2002 г. № 175-Ф3 - 27; от 10 января 2003 г. № 19-Ф3 - 54; от 18 мая 2005 г. - 44; от 22 февраля 2014 г. № 20-Ф3 - 63 раза.

\section{Заключение}

Подводя итоги осуществленного исследования с учетом ранее полученных результатов анализа конституционных и иных актов советского и современного периодов развития российского государства, полагаем предложить авторский подход к систематизации конституционно-правового гарантирования избирательного права, состоящей из различных блоков правовых норм в их хронологическом развитии.

${ }^{1}$ Федеральный закон от 19.09.1997 № 124-Ф3 «Об основных гарантиях избирательных прав и права на участие в референдуме граждан Российской Федерации» // СЗ РФ. 1997. № 38. Ст. 4339.

2 Федеральный закон от 12.06.2002 № 67-Ф3 «Об основных гарантиях избирательных прав и права на участие в референдуме граждан Российской Федерации» (ред. от 23.05.2020) // Российская газета. 2002, 15 июня; 2020, 25 мая. 
Такими блоками норм выступают следующие:

- конституционно-интерпретационные (с 1918 г. по настоящее время) доктринально обоснованы, формализованы в российских конституциях установления, обеспечивающие реализацию искомого права на различных стадиях избирательного процесса;

- подзаконно-интерпретационные (с 1938 по 1977 гг.) доктринально обоснованы, формализованы в самостоятельных особых инструкциях и положениях о выборах различных уровней, а также иных формах подзаконных нормативных правовых актов гарантирующие избирательное право установления;

- фрагментарно-специальные законодательные (с 1978 г. по настоящее время) формализованы в законодательных нормативных правовых актах, посвященных референдуму и выборам различных уровней в корреляции с субъективным избирательным правом и его гарантиями;

- рамочно-специальные законодательные (с 1997 г. по настоящее время) формализованы в особом, специально предназначенном для гарантирования избирательных прав граждан федеральном законе («Об основных гарантиях избирательных прав и права на участие в референдуме граждан Российской Федерации»).

Современный этап гарантирования избирательного права характеризуется интегративностью представленных блоков, за исключением того, что в настоящее время подзаконные акты конкретизируют конституционные и законодательные положения, но не являются единственными в дополнение к конституционным, как это было с 1925 по 1977 гг.

\section{Список литературы}

1. Агишев Р.А. 2014. Конституционные основы и гарантии права человека и гражданина на объединение в Российской Федерации. Ленинградский юридический журнал, 3: 37-46.

2. Вискулова В.В. 2013. О некоторых вопросах теории гарантий избирательных прав граждан. Актуальные проблемы российского права. 4: 411-423.

3. Лошкарев А.В. 2009. Правовые гарантии: теоретические проблемы определения понятия и классификации: Автореф. дис. ... канд. юрид. наук. Краснодар, 25 с.

4. Новикова А.Е. 2007. Институт уполномоченного по правам человека в Российской Федерации (историко-правовой и теоретико-правовой аспекты): Автореф. дис. ... канд. юрид. наук. СПб, 22 с.

5. Нудненко Л.А., Тхабисимова Л.А. 2016. К вопросу о правовом статусе и гарантиях деятельности зарегистрированного кандидата. Государственная власть и местное самоуправление, 11: 34-39.

6. Трещева О.Ю., Балаян Э.Ю. 2019. Конституционные гарантии осуществления, обеспечения и защиты прав и свобод человека и гражданина органами местного самоуправления. Государственная власть и местное самоуправление, 10: 40-45.

7. Троян В.А. 2020. Генезис конституционного гарантирования избирательного права в России: советский период. Наука и образование: хозяйство и экономика; предпринимательство; право и управление, 7(122): 33-37.

8. Федотова Ю.Г. 2017. Проблемы юридических гарантий правового статуса граждан, участвующих в обеспечении национальной безопасности. Государственная власть и местное самоуправление, 8: 3-7.

9. Чихладзе Л.Т., Осавелюк А.М. 2018. Конституция России и проблема гарантий прав и свобод человека. Lex russica, 11: 63-68.

10. Чуклин А.В. 2016. Принципы установления субъектами Российской Федерации дополнительных гарантий реализации конституционных прав и свобод человека и гражданина. Конституционное и муниципальное право, 11: 50-53.

11. Kornyushkina, A.Y., Markhgeym, M.V., Novikova, A.E., Doronina, O.N., Zajcev, S.Y. 2017. Minimization of human rights risks: the constitutional legal experience of post-soviet states. Turkish online journal of design art and communication. V. 7. S-APRLSPCL: 352-356. 


\section{References}

1. Agishev R.A. 2014. Konstitucionnye osnovy i garantii prava cheloveka i grazhdanina na ob"edinenie v Rossijskoj Federacii [Constitutional bases and guarantees of the right of a person and citizen to unite in the Russian Federation]. Leningradskij yuridicheskij zhurnal, 3: 37-46.

2. Viskulova V.V. 2013. O nekotoryh voprosah teorii garantij izbiratel'nyh prav grazhdan [On some issues of the theory of guarantees of citizens ' electoral rights]. Aktual'nye problemy rossijskogo prava, 4: 411-423.

3. Loshkarev A.V. 2009. Pravovye garantii: teoreticheskie problemy opredeleniya ponyatiya i klassifikacii [Legal guarantees: theoretical problems of definition and classification: author's abstract]: Avtoref. dis. ... kand. yurid. nauk. Krasnodar, 25 p.

4. Novikova A.E. 2007. Institut upolnomochennogo po pravam cheloveka v Rossijskoj Federacii (istoriko-pravovoj i teoretiko-pravovoj aspekty) [Institute of the Commissioner for human rights in the Russian Federation (historical-legal and theoretical-legal aspects)]: Avtoref. dis. ... kand. yurid. nauk. $\mathrm{SPb}, 22 \mathrm{p}$.

5. Nudnenko L.A., Thabisimova L.A. 2016. K voprosu o pravovom statuse i garantiyah deyatel'nosti zaregistrirovannogo kandidata [To the question of the legal status and guarantees of the registered candidate]. Gosudarstvennaya vlast' i mestnoe samoupravlenie, 11: 34-39.

6. Treshcheva O.YU., Balayan E.YU. 2019. Konstitucionnye garantii osushchestvleniya, obespecheniya i zashchity prav i svobod cheloveka i grazhdanina organami mestnogo samoupravleniya [Constitutional guarantees for the exercise, maintenance and protection of human and civil rights and freedoms by local self-government bodies]. Gosudarstvennaya vlast' i mestnoe samoupravlenie, 10: 40-45.

7. Troyan V.A. 2020. Genezis konstitucionnogo garantirovaniya izbiratel'nogo prava v Rossii: sovetskij period [Genesis of the constitutional guarantee of the right to vote in Russia: Soviet period]. Nauka i obrazovanie: hozyajstvo i ekonomika; predprinimatel'stvo; pravo i upravlenie, 7(122): 33-37.

8. Fedotova YU.G. 2017. Problemy yuridicheskih garantij pravovogo statusa grazhdan, uchastvuyushchih $\mathrm{v}$ obespechenii nacional'noj bezopasnosti [Problems of legal guarantees of the legal status of citizens involved in ensuring national security]. Gosudarstvennaya vlast' i mestnoe samoupravlenie, 8: 3-7.

9. CHihladze L.T., Osavelyuk A.M. 2018. Konstituciya Rossii i problema garantij prav i svobod cheloveka [The Russian Constitution and the problem of guarantees of human rights and freedoms]. Lex russica, 11: 63-68.

10. CHuklin A.V. 2016. Principy ustanovleniya sub"ektami Rossijskoj Federacii dopolnitel'nyh garantij realizacii konstitucionnyh prav i svobod cheloveka i grazhdanina [Principles of establishing additional guarantees by the subjects of the Russian Federation for the exercise of constitutional rights and freedoms of man and citizen]. Konstitucionnoe i municipal'noe parvo, 11: 50-53.

11. Kornyushkina, A.Y., Markhgeym, M.V., Novikova, A.E., Doronina, O.N., Zajcev, S.Y. 2017. Minimization of human rights risks: the constitutional legal experience of post-soviet states. Turkish online journal of design art and communication. V. 7. S-APRLSPCL: 352-356.

\section{ИНФОРМАЦИЯ ОБ АВТОРЕ}

Троян Владимир Анатольевич, аспирант кафедры конституционного и международного права юридического института Белгородского государственного национального исследовательского университета, г. Белгород, Россия

\section{INFORMATION ABOUT THE AUTHOR}

Vladimir A. Troyan, post-graduate student of the Department of constitutional and international law of the law Institute of the Belgorod state national research University, Belgorod, Russia 